\title{
Prospects for the use of protein-carbohydrate complex based on mung bean seeds in the functional meat products technology
}

\author{
Andrey Alexeev ${ }^{1}$, Tatyana Alexeeva ${ }^{1}$, Larisa Enaleva, ${ }^{2, *}$, Tatyana Tupolskikh ${ }^{2}$, Nataliia \\ Shumskaia ${ }^{2}$ \\ ${ }^{1}$ Don State Agrarian University, 24b, Krivoshlykova St., 346493, Rostov Region, Oktyabrsky \\ District, Persianovsky Village, Russia \\ ${ }^{2}$ Don State Technical University, Gagarina sq., 1, 344003, Rostov-on-Don, Russia
}

\begin{abstract}
The use of new non-traditional types of plant materials in the diet is one of the ways to improve the meat products' quality. The combination of plant proteins with animals creates biologically active amino-acid complexes which increase its bioavailability for organism and biological value of the product. In this case, the use of non-traditional plant materials in the production technology of new types of sausage products to improve the quality of the end product is prospective and relevant. Research objective is development of formulations and technologies for new types of high biological value products, based on combination of meat raw materials with functional additives of plant origin. The work was performed at the Department of Food Technology FSBEI HE «Don State Agrarian University», Persianovsky, Rostov region. The objects of research were the new protein-carbohydrate complexes based on flour from germinated seeds of mung bean, control and model forcemeat based on trim beef of first grade, lean trim pork and mid fat trim pork, and end products. Introduction to the cooked sausage products formulation of mung bean germinated seeds flour has a beneficial effect on the organoleptic properties of the end product and enriches it with biologically valuable substances.
\end{abstract}

\section{Introduction}

Currently, the lifestyle of a modern person has noticeably changed, many factors influence his health, as well as his effective working capacity and emotional state. It includes, first of all, the diet, the level of nervous and physical stress, the environmental state, etc. $[7,11,13]$.

The use of plant materials new types in the diet is one of the ways to improve the products quality. A wide range of functional components of plant origin allows to use it in the meat products production technology. Sources of edible vegetable protein have high biological value, good digestibility, organoleptic appeal [2,4].

\footnotetext{
*Corresponding author: enaleva@yandex.ru
} 
By combining vegetable and animal proteins, protein balance can be achieved. In addition, it was found that the content of one animal or vegetable protein in food has less biological value than the mixture $[8,12]$.

The introduction of protein supplements of plant origin will allow to replace part of the animal protein with vegetable, increase the biological and vitamin value of the product, improve its mineral composition, enrich it with dietary fiber and other valuable components $[5,10]$.

Vegetable raw materials, in comparison with meat, contain large number of micro and macro elements, vitamins, as well as fiber and pectin, acts as a source of necessary biologically active substances, the content of which is insufficient in meat. The use of plant materials in the meat products production contributes to its enrichment with functional ingredients, increase digestibility, as well as to obtain products that meet physiological nutritional standards. It is appropriate to use plant raw materials that grow on the territory of our country and population groups that consume it for food $[6,9,15]$.

Grain legumes are the sources of vegetable protein and find application in food production as ingredients with nutritional, technological and therapeutic value, due to the presence of functional properties. Functional properties are the physical and chemical characteristics of proteins which affect the process, improving consumer, technological and structural properties of the end product. Now the plant proteins functional characteristics study - is one of the leading directions in solving the problem of obtaining fundamentally new forms of food, ensuring recipes and production technologies development for multicomponent food systems, as well as the choice of processes and modes of its processing into finished food products $[1,3,14]$.

As promising sources of plant materials for the biologically active additives creation, along with the secondary resources of the food and processing industries, unconventional raw materials, in particular, grain legume of mung bean and its processed products, are of practical interest.

In this case, the formulations and technologies development for new types of products of high biological value, based on combination of raw meat with functional additives of plant origin, is of particular importance.

\section{Materials and Methods}

Researches was carried out at the Department of Food Technology of the Don State Agrarian University, in the veterinary laboratory of the Taganrog branch SBU RR « Rostov Regional Station for Combating Animal Diseases with Antiepizootic Detachment» and at Ltd «Taganrog Meat Processing Plant». Based on the goals and objectives, selection of research objects and experimental conditions was carried out.

As research objects were used: meat raw materials - trim beef of first grade, lean trim pork, mid fat trim pork; herbal supplement - grain legume of mung bean and its processing products (mung bean flour) and other ingredients according to the formulation. We used the seeds of mung beans leguminous crop, producer Uzbekistan, exporting company TS Markab LLC, Simferopol, Russia.

The raw materials used in the research met the requirements of Customs Union Technical Regulations «On the safety of meat and meat products» (TR TS 034/2013). Sampling of the end product was carried out according to the methods given in GOST R 51447-99 «Meat and meat products. Sampling Methods». Determination of the protein mass fraction was carried out according to GOST 25011-2017 «Meat and meat products. Methods for determining protein». Determination of moisture mass fraction was carried out by drying in an oven at a temperature of $130^{\circ} \mathrm{C}$, according to the method of GOST 97932016 «Meat and meat products. Moisture determination methods». Organoleptic evaluation 
of the end product was carried out in accordance with GOST 9959-2015 «Meat and meat products. General conditions for organoleptic assessment». Determination of the main functional and technological indicators of forcemeat (water-holding, moisture-binding and fat-holding abilities) was carried out in accordance with GOST R 51479-99 (ISO 1442-97) «Meat and meat products».

\section{Results}

Taking into account the fact that the proportion of vegetable protein should be at least half the human protein diet, the search for new sources of vegetable protein and ways to improve its amino-acid composition is prospective. To this end, to substantiate the choice of the object of study, work was carried out to study the mung bean chemical composition (Table 1).

Table 1. Chemical composition of the studied mung bean seeds.

\begin{tabular}{|c|c|}
\hline Index & Mass fraction, \% sv \\
\hline Moisture and volatile matter & 11.71 \\
Proteins & 21.63 \\
Fats & 2.64 \\
Carbohydrates & 61.80 \\
Cellulose & 3.50 \\
\hline
\end{tabular}

The main functional and technological properties of the protein include solubility in water, water holding $(\mathrm{WH})$, fat holding $(\mathrm{FH})$, fat emulsifying $(\mathrm{FE})$ and foam forming abilities (FFA).

The water holding ability is characterized by water adsorption with the participation of hydrophilic amino acid residues, and the fat holding ability is characterized by adsorption of fat due to hydrophobic residues. At low humidity, hydrophilic groups, interacting with water molecules, form a monomolecular layer.

The ability of proteins to retain fat and water depends not only on the characteristics of the amino acid composition and structure, but also on the fractional composition, processing method, medium $\mathrm{pH}$, temperature and presence of carbohydrates, lipids and other proteins. The high ability of proteins to retain water in meat products increases yield, lengthens shelf life and improves texture.

Functional and technological properties of the studied leguminous crops are presented in table 2.

Table 2. Functional and technological properties of mung bean.

\begin{tabular}{|c|c|}
\hline Index & Quantity \\
\hline WH, g/g & 4.72 \\
FH, g/g & 4.44 \\
FE, \% & 55.35 \\
FFA, \% & 53.33 \\
\hline
\end{tabular}

The high index of fat emulsifying ability of the mung bean leguminous crop allows to recommend for the production technology of meat products. Biological value of mung bean leguminous crops was determined using microscopic infusorian Tetrachymena pyryphormis. Casein protein was used as a control.

The results of the studies indicate that in the mung bean seeds there was a high growth of microorganisms. It can be assumed that a high level of relative biological value of mung bean is due to a higher balance of amino-acid composition. 
Mung bean showed high results for WH, FH, FE, FFA, as well as for relative biological value. The obtained data allows to conclude that it is advisable to use the legume crop of mung bean as a plant origin protein supplement when creating functional meat products.

The research methodology provided for the directed modification of mung bean seeds. To do this, we used the most promising and safe method of enzymatic modification, based on the seed enzyme system activation, which occurs during germination. Of the most known legumes, mung bean is the only easy-to-grow crop.

As the optimal medium for studied object enzyme system activating, drinking water was used. Mung bean seeds germination was carried out at room temperature in plastic container, seeds of the leguminous crop were laid in one layer, then covered with a layer of drinking water. To determine the functional and technological properties of seeds, water level control and sampling were carried out every 12 hours. To inactivate the enzymes, the samples of germinated seeds were subjected to heat treatment at $\mathrm{t}=105^{\circ} \mathrm{C}$ for 10 minutes.

Research data indicates that the leguminous crop changes its water-holding ability depending on germination time.

Mung bean gave the first sprouts in 12 hours. Analysis of water holding capacity was carried out for 60 hours, however, after 2 days of germination, the growth trend of the analyzed indicator decreased, which gives reason to establish the optimal germination time - 48 hours. Decreasing in this indicator is explained by the fact that the mung bean accumulated the optimal amount of moisture in 48 hours, which contributed to the seed internal enzymatic system complete activation.

Fat holding ability, as well as water-holding, when germinated, increases indicators from 4.5 to $5.7 \mathrm{~g} / \mathrm{g}$; changes go smoothly, without sharp fluctuations in time.

According to the obtained data, after the first 12 hours of germination, the fat emulsifying ability of the mung bean seeds decreases. Further, the lowering process of FH is completed by $46 \%$, which is caused by the interaction of water and the hydrophilic parts of the protein, while lowering the diphilic properties.

The conducted studies suggest that the most optimal conditions for the growth of the main functional and technological properties are achieved by germinating mung bean seeds for 48 hours at room temperature, during which the water holding, fat holding and fat emulsifying abilities acquire the highest rates.

Table 3 presents comparative assessment of sprouted mung bean seeds with the initial chemical and fractional compositions.

Table 3. Comparative evaluation of sprouted mung bean seeds with the initial chemical and fractional compositions.

\begin{tabular}{|c|c|c|}
\hline Indicators. mass fraction. sv & $\begin{array}{c}\text { Mung bean seeds before } \\
\text { modification }\end{array}$ & $\begin{array}{c}\text { Mung bean seeds after } \\
\text { modification }\end{array}$ \\
\hline Cellulose & 3.8 & 1.8 \\
\hline Carbohydrates & 55.48 & 11.06 \\
\hline Fats & 1.9 & 0.8 \\
\hline Proteins & 22.13 & 27.51 \\
\hline Ash & 5.04 & 2.02 \\
\hline Moisture & 10.72 & 56.81 \\
\hline
\end{tabular}

The presented data indicates that the sprouted mung bean contain the largest amount of protein, which allows us to judge the increased biological and nutritional value of the modified mung bean; it has been estimated not only the plant's enzyme system activation, which contributed to amino-acid composition changing, but also its mass doubled due to the protein's high hydrophilicity, which is a very important factor in meat products production. In the germination process, fat content decreased, which is an important factor when creating functional meat products. 
The conducted studies allow to recommend the use of modified mung bean in the functional foods production, as a source of protein containing all the essential amino-acids.

The proposed enzymatic modification mode contributed to the protein supplements production with more balanced amino-acid composition and high biological value, which indicates the prospects of its use as raw material in functional meat products production.

It is known that grinding seeds of legumes contributes to an increase in the number of hydrophilic and hydrophobic centers and favorably affects the functional and technological properties of the produced products.

By grinding method on bindings of germinated seeds, a batch of flour was developed from the food grade of mung bean leguminous crop with a yield of end part of at least $60 \%$. Depending on grinding degree, grinding fineness was determined by sieve analysis method.

In appearance, the finely ground mung bean flour is a fine powder from light yellow to gray color. The main organoleptic characteristics of flour from mung bean seeds are presented in table 4.

Table 4. Organoleptic characteristics of mung bean seed flour.

\begin{tabular}{|c|c|}
\hline Indicator Name & Fine mung bean flour characteristics \\
\hline Appearance & Fine powder \\
\hline Color & Light yellow to gray \\
\hline Taste & Peculiar to mung bean flour, with characteristic bean taste, \\
without extraneous tastes
\end{tabular}

The mung bean flour is characterized by rich pronounced odor of bean culture with yellowish tint. Flour has a high nutritional value according to the main physical and chemical indicators (table 5).

Table 5. Nutritional value of mung bean processing products.

\begin{tabular}{|l|c|}
\hline \multicolumn{1}{|c|}{ Indicator Name } & Mung bean flour \\
\hline Mass fraction. \% & $12 \pm 0.3$ \\
Moisture & $3.0 \pm 0.2$ \\
\hline Fat & $21.4 \pm 0.4$ \\
\hline Protein & $42.0 \pm 0.3$ \\
\hline Carbohydrates & $3.5 \pm 0.1$ \\
\hline Ash & $18.5 \pm 0.3$ \\
\hline Cellulose & $0.4 \pm 0.2$ \\
\hline Saturated fatty acids & 300.0 \\
\hline Energy value. kcal & \\
\hline
\end{tabular}

The feature of mung bean flour is high protein content. According to this indicator, the studied additive has optimal values, which indicates high biological value. Lower fat content and high amount of fiber allow the use of mung bean flour as a functional additive. The amino-acid content in mung bean flour from germinated seeds is shown in table 6 .

Table 6. Amino-acid content in mung bean flour from germinated seeds.

\begin{tabular}{|l|c|c|c|}
\hline \multirow{2}{*}{\begin{tabular}{c}
\multirow{2}{*}{$\begin{array}{c}\text { Biochemical } \\
\text { indicator }\end{array}$} \\
\cline { 2 - 3 }
\end{tabular}} & \multicolumn{2}{|c|}{ Mung bean flour } & $\begin{array}{c}\text { The ideal consumption of ideal } \\
\text { plant origin protein according } \\
\text { to WHO. per day }\end{array}$ \\
\hline Irreplaceable amino-acids g protein & rate. \% & 5.0 \\
\hline Valine & 5.2 & 104.0 & 7.0 \\
\hline Leucine & 7.2 & 107.1 & 4.0 \\
\hline Isoleucine & 4.2 & 105.0 & 4.0 \\
\hline Threonine & 4.3 & 107.5 & \\
\hline
\end{tabular}




\begin{tabular}{|c|c|c|c|}
\hline Lysine & 5.8 & 105.4 & 5.5 \\
\hline Methionine & 3.6 & 102.9 & 3.5 \\
\hline Phenylalanine & 4.9 & 81.7 & 6.0 \\
\hline Tryptophan & 0.9 & 90.0 & 1.0 \\
\hline \multicolumn{4}{|c|}{ Replaceable amino-acids } \\
\hline Arginine & 11.3 & 102.7 & 11.0 \\
\hline Histidine & 2.6 & 104 & 2.5 \\
\hline
\end{tabular}

When assessing the amount of irreplaceable amino-acids contained in mung bean flour from germinated seeds, the values corresponding to the optimal ratio of «ideal protein» were obtained. An important indicator evaluating the measure of approximation to an ideal protein is the amino-acid rate. The limiting amino-acids are phenylalanine and tryptophan.

The research methodology included the study of the effect of mung bean flour from germinated seeds on the technological properties of forcemeat model systems. As a control sample there was used forcemeat, consisting of trim beef of the first grade, trim mid fat pork and mid back fat.

Mung bean flour from germinated seeds was introduced into the experimental model stuffing systems, replacing part of the first grade beef varieties with flour in an amount of $10 \%-20 \%$ (Table 7 ).

Table 7. Recipes experienced model forcemeats.

\begin{tabular}{|l|c|c|c|c|}
\hline \multirow{2}{*}{ Name of ingredients } & \multirow{2}{*}{ Control } & \multicolumn{3}{c|}{ Replacement level } \\
\cline { 3 - 5 } & & $\mathbf{1 0 \%}$ & $\mathbf{1 5 \%}$ & $\mathbf{2 0 \%}$ \\
\hline Unsalted raw materials, kg (to 100 kg of raw materials) \\
\hline Trim beef of 1st grade & 60.0 & 50.0 & 45.0 & 40.0 \\
\hline Trim lean pork & 25.0 & 25.0 & 25.0 & 25.0 \\
\hline Mid back fat & 15.0 & 150 & 15.0 & 15.0 \\
\hline Sprouted mung bean flour & - & 4 & 6 & 8 \\
\hline Water for hydration & - & 6 & 9 & 12 \\
\hline Total & 100.0 & 100.0 & 100.0 & 100.0 \\
\hline
\end{tabular}

Assessing the qualitative advantages of forcemeat systems with the addition of functional elements, it was noted that in relation to the control, in experimental where flour was introduced in the amount of $10 \%, 15 \%$ and $20 \%$ instead of raw meat, the $\mathrm{pH}$ value increased by $0.02-0.06$.

According to the obtained data, with an increase in the amount of finely dispersed additive, the stability of the emulsion, which is able to bind moisture and fats, increases, and in parallel meat $\mathrm{pH}$ increases.

Change in the active reaction of forcemeat to the alkaline side is due to the alkaline phase of the protein components. Due teh increasing of $\mathrm{pH}$, the hydrophilicity of the entire meat system changes. This pattern was reflected in the functional and technological properties of experimental samples.

Due the laboratory studies, it was found that an increase in the weight volume of the introduced ingredients from the mung bean flour from germinated seeds contributed to the increase in forcemeat composition moisture-binding ability. Moisture-binding ability increased due to swelling of the carbohydrate complex of herbal supplements (Figure 1). 


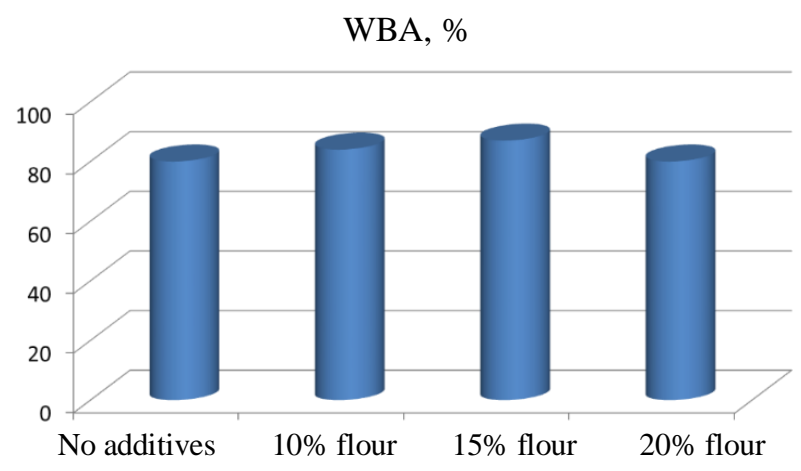

Fig. 1. Dependence of forcemeat moisture-binding capacity on the additive weight, $\%$.

The meat system water-holding ability also varied depending on the amount of introduced plant ingredients containing cellulose and soluble polyglycans (Figure 2).

WHC, $\%$

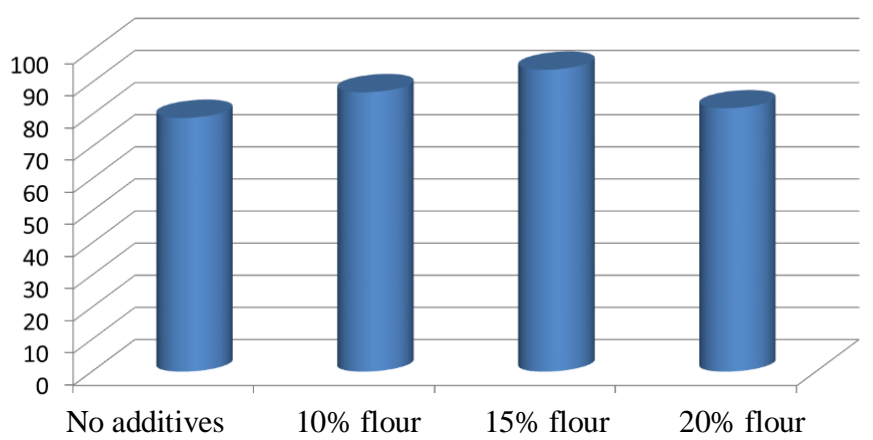

Fig. 2. Dependence of forcemeat water-holding ability on the additive weight, $\%$.

Another significant functional and technological indicator is viscosity. The obtained viscosity values of the forcemeat system are shown in Figure 3. In confirmation of the technological practicability of use, enriched with the functionally active substances of mung bean flour when creating the forcemeat composition, these components had beneficial effect on the mass viscosity. The highest value of the effective mass viscosity was established when making $15 \%$ additives in the forcemeat. With addition of $20 \%$, the viscosity of the system decreases, and the enrichment of the meat complex by $10 \%$ with mung bean flour does not change the viscosity, it is comparable with the control sample.

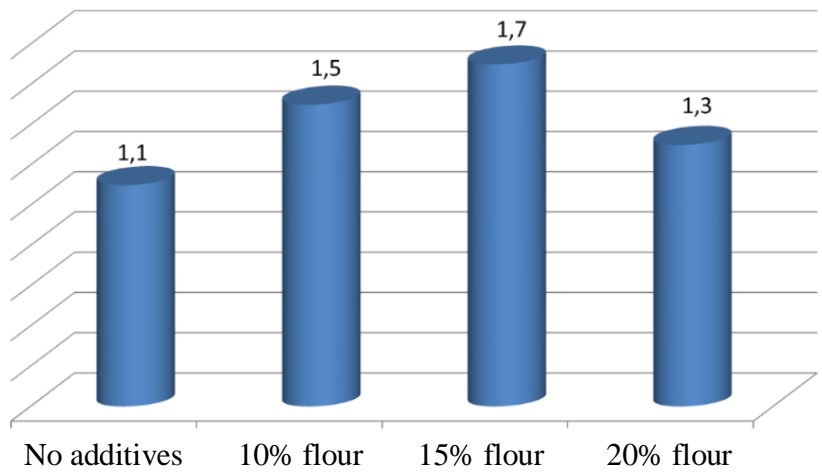

Fig. 3. Mung bean additive viscosity, $\mathrm{Pa}^{*} \mathrm{~s}$. 
Thus, texotropic properties of the combined forcemeat depend on the added additives structural elements and the level of its interaction with water and fat, which is coordinated by the optimal amount of plant ingredients added.

As the functional ingredient basis there was used mung bean flour from germinated seeds, in order to improve the additive chemical composition, since the germination process activates metabolism and respiration, enriches the seeds with enzymes, vitamins and antioxidants. Due germinating, the number of soluble proteins increases, important functional and technological indicators - moisture-binding fat holding ability - improve.

Legume seed flour is an important stabilization system. Preliminary hydration of the protein with the production of dispersions contributes to an increase in the main structural and technological parameters of forcemeat. The method is accompanied by mixing an icewater mixture with portion of flour, short exposure and subsequent technological methods by the traditional method.

The introduction of protein ingredients into flour from non-traditional vegetable raw materials into the cooked sausages formation, favorably affects the functional and technological characteristics and stability of the minced systems, the organoleptic properties of the finished product and enriches it with biologically valuable substances.

The main direction in the preparation of new combined meat system forms is the development of prescription formation which combines the optimal levels of compatibility of forcemeat and vegetable ingredients.

Development of cooked sausages prototypes with different replacement level of raw meat with vegetable protein using mung bean flour from germinated seeds was carried out on the basis of sausage recipes «Otdelnaya» (control sample) GOST R 52196-2015 «Cooked sausages: Technical specifications». The formulation of cooked sausages prototypes with different replacement level of raw meat is presented in the table 8 .

Table 8. Recipe prototypes of cooked sausages.

\begin{tabular}{|l|c|c|c|c|}
\hline \multicolumn{1}{|c|}{ Name of ingredients } & Control sample & \multicolumn{3}{|c|}{ Replacement level } \\
\cline { 3 - 5 } & \multicolumn{1}{|c|}{$\mathbf{1 0 \%}$} & $\mathbf{1 5 \%}$ & $\mathbf{2 0 \%}$ \\
\hline Unsalted raw materials, kg (to 100 kg of raw materials) & \multicolumn{2}{|c|}{} & \\
\hline Trim beef of 1st grade & 60.0 & 50.0 & 45.0 & 40.0 \\
\hline Trim lean pork & 25.0 & 25.0 & 25.0 & 25.0 \\
\hline Mid back fat & 15.0 & 15.0 & 15.0 & 15.0 \\
\hline $\begin{array}{l}\text { Sprouted mung bean } \\
\text { flour }\end{array}$ & - & 4 & 6 & 8 \\
\hline Water for hydration & - & 6 & 9 & 12 \\
\hline Total & 100.0 & 100.0 & 100.0 & 100.0 \\
\hline Nutritional supplements, spices, materials, g (to 100 kg of raw materials) & & \\
\hline Sugar & 150 & 150 & 150 & 150 \\
\hline Common salt & 2500,0 & 2500,0 & 2500,0 & 2500,0 \\
\hline Sodium nitrite & 6.4 & 6.4 & 6.4 & 6.4 \\
\hline Black pepper & 100,0 & 100,0 & 100,0 & 100,0 \\
\hline Allspice & 100,0 & 100,0 & 100,0 & 100,0 \\
\hline Fresh garlic & 120,0 & 120,0 & 120,0 & 120,0 \\
\hline
\end{tabular}

When choosing products from raw meat, consumer preferences are based on the sold product appearance, reasonable price in relation to goods of similar segment, as well as nutritional benefits of the tasting.

The main quality indicators of the experimental samples of cooked sausages with different replacement level of raw meat with high-protein complex in the form of mung 
bean flour from germinated seeds, has been evaluated. Cooked sausage «Otdelnaya» developed according to the traditional recipe was used as a control (Table 9).

Table 9. The main quality indicators of prototypes of cooked sausages with different level of replacement of raw meat.

\begin{tabular}{|c|c|c|c|c|c|}
\hline \multirow{3}{*}{$\begin{array}{l}\text { Name of } \\
\text { indicator }\end{array}$} & \multicolumn{5}{|c|}{ Characteristic indicator } \\
\hline & \multirow{2}{*}{ Control } & \multicolumn{3}{|c|}{ Replacement level } & \multirow{2}{*}{$\begin{array}{l}\text { GOST R requirements } \\
52196-2003\end{array}$} \\
\hline & & $10 \%$ & $15 \%$ & $20 \%$ & \\
\hline Appearance & \multicolumn{5}{|c|}{$\begin{array}{l}\text { Linksausage with clean and dry surface, without damage to the shell, forcemeat } \\
\text { influx, slips, soup and fat swelling, voids. }\end{array}$} \\
\hline Consistency & \multicolumn{4}{|c|}{ Elastic } & Elastic \\
\hline $\begin{array}{l}\text { Color and type } \\
\text { of forcemeat in } \\
\text { section }\end{array}$ & Pink & Light pink & Light pink & Light gray & $\begin{array}{c}\text { Pink or light pink } \\
\text { forcemeat, evenly } \\
\text { mixed, contains pieces } \\
\text { of white colored or } \\
\text { pinkish tint fat, side } \\
\text { size not more than } 6 \\
\text { mm } \\
\end{array}$ \\
\hline Odor and taste & \multicolumn{2}{|c|}{$\begin{array}{l}\text { Peculiar to current type } \\
\text { of product, with odor of } \\
\text { spices and mild salty }\end{array}$} & $\begin{array}{l}\text { Peculiar to } \\
\text { current type of } \\
\text { product, light } \\
\text { bean odor }\end{array}$ & $\begin{array}{l}\text { Specific odor } \\
\text { and delicate } \\
\text { taste of beans }\end{array}$ & $\begin{array}{l}\text { Peculiar to current type } \\
\text { of product, with odor of } \\
\text { spices and mild salty }\end{array}$ \\
\hline
\end{tabular}

Analysis of the obtained data indicates that the experimental samples of cooked sausages with the introduction of additives up to $15 \%$ in organoleptic indicators are not inferior to the control samples.

All presented cooked sausages samples had traditional appearance for current type of product - linksausages with clean and dry surface, without damage to the shell, forcemeat influx, slips, soup and fat swelling, voids; possessed juicy and at the same time elastic consistency; no differences in this samples according to these indicators were revealed. In all sausage samples the odor of spices was quite perceptible; in the prototype with $20 \%$ replacement level, specific odor and light taste of beans were noted. The main differences in the cooked sausages samples were established at color intensity assessing. Visual assessment of cooked sausages color showed that the control sample had more intense color compared to others that had close shade of color, but the sample with $20 \%$ replacement level still had light gray color. The scoring results of the cooked sausages experimental samples organoleptic characteristics are presented in table 10.

Table 10. The results of cooked sausages prototypes organoleptic characteristics' scoring.

\begin{tabular}{|l|c|c|c|c|c|c|}
\hline $\begin{array}{c}\text { Cooked sausage } \\
\text { samples }\end{array}$ & $\begin{array}{c}\text { Marketable } \\
\text { condition }\end{array}$ & Color & Odor & Consistency & Taste & $\begin{array}{c}\text { Average } \\
\text { score }\end{array}$ \\
\hline Control sample & 4.9 & 5.0 & 5.0 & 4.8 & 4.9 & 4.92 \\
\hline Replacement level 10\% & 4.9 & 4.9 & 5.0 & 4.8 & 4.9 & 4.90 \\
\hline Replacement level 15\% & 4.9 & 4.9 & 5.0 & 4.8 & 4.8 & 4.88 \\
\hline Replacement level 20\% & 4.9 & 4.7 & 4.8 & 4.8 & 4.7 & 4.78 \\
\hline
\end{tabular}

Tasting monitoring indicates that samples containing protein supplement from mung bean flour from germinated seeds in an amount of 10 to $15 \%$ instead of raw meat became optimal for visual assessment and taste. In view of high nutritional value of additives from non-traditional proteinaceous plant materials, as well as to rationalize the use of meat resources, the studies provided for physico-chemical quality indicators assessment of cooked sausages experimental samples.

Table 11 shows the cooked sausages prototypes physico-chemical quality indicators. 
Analysis of the data indicates that, according to physicochemical parameters, the cooked sausages prototypes comply with the requirements of GOST 33673-2015 «Cooked sausages. General specifications».

Table 11. Physico-chemical quality indicators of cooked sausages samples with different level of replacement of raw meat.

\begin{tabular}{|c|c|c|c|c|c|}
\hline \multirow[t]{3}{*}{ Name of indicator } & \multicolumn{4}{|c|}{ Name of indicator } & \multirow{3}{*}{$\begin{array}{l}\text { Requirements of } \\
\text { GOST 33673-2015 }\end{array}$} \\
\hline & \multirow{2}{*}{$\begin{array}{l}\text { Control } \\
\text { sample }\end{array}$} & \multicolumn{3}{|c|}{ Meat replacement level } & \\
\hline & & $10 \%$ & $15 \%$ & $20 \%$ & \\
\hline Mass fraction of moisture. $\%$ & 60.7 & 63.2 & 63.7 & 63.5 & No more than 66.0 \\
\hline Mass fraction of protein. $\%$ & 11.3 & 12.1 & 12.3 & 12.7 & No less than 11.0 \\
\hline Mass fraction of fat. $\%$ & 20.1 & 19.9 & 19.6 & 19.3 & No more than 24.0 \\
\hline Mass fraction of chloride & $23+3+2$ & 20 & 1 & 20 & No more thon 2 \\
\hline Mass fraction of sodium nitrite. & & & & & \\
\hline & 0.005 & 0.005 & 0.005 & 0.005 & No more than 0.005 \\
\hline
\end{tabular}

The moisture content in the experimental samples averaged $63.4 \%$, in the control $60.7 \%$, which meets the requirements of GOST 33673-2015.

The results of cooked sausages prototypes chemical analysis indicate the practicability of functional components using, such as flour from modified mung bean seeds, in sausage production technology.

The use of plant ingredients with wide range of biologically useful properties in the cooked sausages production technology is associated with enrichment of product with dietary cellulose, vitamins, macro- and microelements, as well as with reduction in raw material costs.

The research methodology included the cooked sausages production economic efficiency calculation with the use of protein supplement based on germinated mung bean seeds. Calculation of the main raw materials cost for production of $100 \mathrm{~kg}$ of cooked sausages according to the traditional recipe and developed, using mung bean germinated seeds flour, is presented in table 2 .

Table 12. Calculation of basic raw materials cost for the production of cooked sausages with addition of mung bean flour from germinated seeds.

\begin{tabular}{|c|c|c|c|c|c|c|c|}
\hline \multirow{3}{*}{$\begin{array}{l}\text { Name of } \\
\text { the } \\
\text { main } \\
\text { raw } \\
\text { materia } \\
\text { l }\end{array}$} & \multirow{3}{*}{$\begin{array}{l}\text { Cost of } \\
1 \mathrm{~kg}, \\
\text { rub. }\end{array}$} & \multirow{2}{*}{\multicolumn{2}{|c|}{ Control sample }} & \multicolumn{4}{|c|}{ Replacement level } \\
\hline & & & & \multicolumn{2}{|c|}{$10 \%$} & \multicolumn{2}{|l|}{$15 \%$} \\
\hline & & $\begin{array}{l}\text { Consu } \\
\text { mption, } \\
\text { kg }\end{array}$ & Cost, rub. & $\begin{array}{l}\text { Consump } \\
\text { tion, kg }\end{array}$ & Cost, rub. & $\begin{array}{l}\text { Consu } \\
\text { mption } \\
, \mathrm{kg}\end{array}$ & $\begin{array}{l}\text { Cost, } \\
\text { rub. }\end{array}$ \\
\hline $\begin{array}{l}\text { Trim } \\
\text { beef of } \\
1 \text { st } \\
\text { grade }\end{array}$ & 360,00 & 60,00 & 21600,00 & 50,00 & 18000,00 & 45,00 & 16200,00 \\
\hline $\begin{array}{l}\text { Trim } \\
\text { mid fat } \\
\text { pork }\end{array}$ & 220,00 & 25,00 & 5500,00 & 25,00 & 5500,00 & 25,00 & 5500,00 \\
\hline $\begin{array}{l}\text { Mid } \\
\text { back fat }\end{array}$ & 150,00 & 15,00 & 2250,00 & 15,00 & 2250,00 & 15,00 & 2250,00 \\
\hline $\begin{array}{l}\text { Sproute } \\
\text { d mung } \\
\text { bean } \\
\text { flour }\end{array}$ & 140,00 & - & - & 4,00 & 560,00 & 6,00 & 840,00 \\
\hline
\end{tabular}




\begin{tabular}{|l|l|l|l|l|l|l|l|}
\hline $\begin{array}{l}\text { Water } \\
\text { for } \\
\text { hydratio } \\
\mathrm{n}\end{array}$ & 0,025 & - & - & 6,00 & 0,15 & 9,00 & 0,22 \\
\hline Total & & 100,00 & 29350,00 & 100,00 & 26310,15 & 100,00 & 24790,22 \\
\hline
\end{tabular}

The obtained data indicate that the cost of basic raw materials for the prototypes production is significantly lower than for control. The economic efficiency calculation confirms the practicability of using mung bean flour from germinated seeds in the production technology for cooked sausages. The economic effect at $10 \%$ level of replacing meat raw materials with protein-based vegetable supplement amounted to 3,039.85 rubles, with $15 \%$ level replacing meat raw materials $-4,559.78$ rubles.

\section{Discussion}

Studies on the technology development and consumer properties evaluation of cooked sausages with unconventional fillers based on protein-based vegetable additives from mung bean flour from germinated seeds led to the following conclusions:

1. Practicability of using mung bean flour from germinated seeds in the production technology of combined cooked sausages for functional purposes is associated with the enrichment of the product with dietary fiber, vitamins, macro- and microelements, as well as with reduction in raw material costs.

2. Introduction of protein ingredients in the form of flour from non-traditional vegetable raw materials into the formation of cooked sausages favorably affects the functional and technological characteristics and stability of forcemeat systems, organoleptic properties of the end product and enriches it with biologically valuable substances.

3. Analysis of the data indicates that, according to physicochemical parameters, the prototypes of cooked sausages meet the requirements of GOST 33673-2015. It is established that the use of mung bean flour from germinated seeds in the cooked sausages production technology contributes to the increase in nutritional value and the yield of the end product.

4. It was found that in experimental samples with the addition of mung bean flour from germinated seeds containing active stabilization elements of the meat system, an increase in the solidity and density of forcemeat is observed, at the same time when studying organoleptic characteristics, the experimental samples have more delicate texture compared to the control.

5. Study of microbiological safety indicators for cooked sausages shows that all samples of cooked sausages with plant origin protein supplement, according to microbiological safety indicators, meet the requirements of SanPiN.

6. Calculation of the cost of the main raw materials confirms the economic practicability of the production of cooked sausages with the meat raw material part replacement with mung bean flour from germinated seeds.

\section{References}

1. E.A. Baldwin, J. Bai, A. Plotto, Sensors 11(5), 4744-4766 (2011)

2. A.V. Bannikova, I.A. Evdokimov, Foods and Raw Materials 3(2), 3-12 (2015)

3. N. Bibi, Z. Mehmood, A. Zeb, M. Khan, R.A. Anis, Journal of Food Science and Engineering 1, 56-61 (2011) 
4. E. Casala, C. Matthys, S. Péter and others, Trends in Food Science \& Technology 37(2), 152-161 (2014)

5. G.A. Dorn, T.V. Savenkova, O.S. Sidorova, O.V. Golub, Foods and Raw Materials 3(1), 70-76 (2015)

6. M. Elleuch, D. Bedigian, O. Roiseux, S. Besbes, C. Blecker, H. Attia, Food Chemistry 124(2), 411-421 (2011)

7. Ke-Ying Qian, Structure-Function Relationship of Flaxseed Gum from Flaxseed Hulls (The University of Guelph, Canada, 2014)

8. A.G. Khramtsov, I.A. Evdokimov, A.D. Lodygin, R.O. Budkevich, Foods and Raw Materials 2(1), 22-26 (2014)

9. L. Wenhao, Z. Fusheng, L. Peilin, B. Yunfei, G. Lin, S. Qun, J. Food Eng. 4, 388-393 (2011)

10. A.V. Moroni, S. Iametti, F. Bonomi, Food Chem. 4, 1225-1230 (2010)

11. O.N. Musina, P.A. Lisin, Foods and Raw Materials 3(2), 65-73 (2015)

12. N. Harri, L. Thibaul, Nutrition Research Reviews 23, 299 (2010)

13. A. Ronteltap, S.J. Sijtsema, H. Dagevos, M.A. Winter, Appetite 59(2), 333-340 (2012)

14. S. Shravani, Journal of Food Science and Engineering 2, 411-426 (2012)

15. L.V. Tereshchuk, K.V. Starovoitova, Foods and Raw Materials 1(2), 67-75 (2013) 